\title{
SÁNTA SÁRA \\ Schönvisner István és a szombathelyi püspöki könyvtár megalapítása
}

\section{Bevezetés}

Az 1777-ben megalakult Szombathelyi Püspökség első püspöke, Szily János (1735-1799) első intézkedései közé tartozott, hogy az újonnan alapított egyházmegyében könyvtárat is létrehozzon, melyet az épülő székesegyháznak ajánlott fel. A bibliotéka állományának összeállításában kezdetben Schönvisner István (1738-1818), a pesti Egyetemi Könyvtár őre volt a segítségére. Tanulmányomban a könyvtár megalakulásának folyamatából azt az időszakot szeretném ismertetni, amely kifejezetten Schönvisnerhez kapcsolódik.

A korabeli könyvbeszerzések lebonyolításának ismertetése után azt igyekszem bemutatni, hogy kezdetben milyen volt a gyüjtemény tematikus megoszlása. Ezen belül részletesebben is beszélni szeretnék a Historici profani szak nyomtatványairól. A püspök és Schönvisner levelezéséből azonosított kötetek provenienciájának vizsgálata alapján pedig megpróbálom felvázolni, hogy mely feloszlatott szerzetesrendi könyvtárak állományából épülhetett fel az új püspöki könyvtár az első években.

Schönvisner István, az Egyetemi Könyvtár és az aboliciós könyvek

Mária Terézia rendeletére 1777. február 17-én alakult meg a Szombathelyi egyházmegye, melynek élére a pápa Szily Jánost nevezte ki megyéspüspökké. Szily a soproni jezsuitáknál kezdte meg tanulmányait, majd 1755-1758 között a római Collegium Germanicum-Hungaricum hallgatója volt. Az ott megismert ókori emlékek, valamint a várost uraló barokk építészet egész későbbi gondolkodását és munkásságát meghatározták. Miután Rómából hazatért, pártfogója, Zichy Ferenc győri püspök udvarába került, ahol összesen tizenhét évet töltött. A római évek után a Győrben töltött idő is nagy hatással volt az ifjú Szilyre, aki Zichy püspök mellett az egyházszervezésben és a müpártolásban is tapasztalatot szerezhetett. Püspöke megbízásából ő intézte ugyanis például a győri székesegyház felújításának ügyeit: ekkor került kapcsolatba többek között Melchior Hefele építőmesterrel és Franz Anton Maulbertsch-csel, az egyik legjelentősebb hazai barokk freskófestővel is. Ök később Szily felkérésére a Szombathelyi egyházmegye újonnan emelt épületeinek elkészítésében is tevékenyen részt vettek. 
Szily János amellett, hogy megszervezte az új egyházmegye müködését, beiktatása után azonnal nekilátott a püspöki székhely kulturális intézményrendszerének kiépítéséhez is. ${ }^{1}$ Szily első intézkedései egyike volt, hogy papnevelö intézetet hozzon létre, és egyházmegyéje számára természetesen egy könyvtárat is tervezett. ${ }^{2}$ A gyüjtemény megalapozásában több könyvügynök is segítségére volt. Bécsben ketten is - Anton Kurz és Johann Georg Binz figyelték számára az aktuális árverési katalógusokat, ${ }^{3}$ Pestről pedig Schönvisner István, az Egyetemi Könyvtár őre tájékoztatta rendszeresen a könyvpiac kínálatáról. ${ }^{4}$

A tudós Schönvisner és a mecénás Szily püspök közös munkájának eredményeképpen az 1791. év Szombathely kulturális életében két szempontból is mérföldkőnek tekinthető. Egyfelől ekkor jelent meg Schönvisnernek a város történetét feldolgozó Antiquitatum et Historiae Sabariensis... címü müve, ${ }^{5}$ másfelől az év végén nyílt meg a püspöki könyvtár. ${ }^{6}$

Pontos információink nincsenek arról, hogy a tudós könyvtáros miként került Szily püspök látókörébe. Azt tudjuk, hogy a 18. század végén hazánkban a könyvvásárlási lehetőségek igen korlátozottak voltak, így ahhoz, hogy könyvtárát fel tudja építeni, Szilynek segítségre volt szüksége. Könyvbeszerzésre az ország egyik kulturális központjában, Budán volt lehetősége. A fennmaradt levelezés tanúsága szerint a bécsi ügynökökkel csak az 1790-es években tárgyalt, tehát a

1 Szily János szombathelyi püspök életútjáról és tevékenységéről lásd: GéFIn Gyula, A szombathelyi székesegyház és egyházmegye története. I. Szombathely, a szerző kiadása, 1929. A püspök művészeti mecenatúrájáról máig alapvető monográfia: GALAvICs Géza, Program és müalkotás a 18. század végén, Egy festmény születése és fogadtatása, Bp., Akadémiai, 1971 (Művészettörténeti füzetek, 2).

2 A könyvtár alapításával kapcsolatos irodalom: GÉFIN 1929, i. m. 86-87; PATAKI László, A szombathelyi egyházmegyei könyvtár története = A 200 éves szombathelyi egyházmegye emlékkönyve (1777-1977), szerk. Fábián Árpád, Szombathely, Vas megyei Nyomda, 1977, 433-439; Dobri Mária, A Szombathelyi Egyházmegyei Könyvtár története 1791-1991 = Vasi Szemle, 45(1991), 522-524; Sill Ferenc, Szily János püspök könyvtáralapitása = Vasi Szemle, 47(1993), 97-100. Meg kell jegyeznünk, hogy a témával kapcsolatban érdemi kutatások nem történtek, az itt felsorolt irodalom általánosságban foglalkozik csak az alapítás kérdésével.

3 A könyvügynökökkel az 1790-es években folytatott levelezése megtalálható a Szombathelyi Egyházmegyei Könyvtár kézirattárában: SZEK Szily János iratai (a továbbiakban SZEK Szily), III. A székesegyházi könyvtár könyvbeszerzéseivel kapcsolatos levelezés.

4 SZEK Szily II., 6. Szily és Schönvisner. A püspök levelezésében nem találunk olyan adatot, amely bizonyítaná, hogy Schönvisneren kívül más szakember segítségét is igénybe vette volna a könyvtár megnyitását megelőző években, erről információk kizárólag az 1790-es évekből származnak.

${ }_{5}$ Schönvisner, Stephanus, Antiquitatum et historiae Sabariensis ab origine usque ad praesens tempus libri novem, Pestini, Typis Matthiae Trattner, 1791. Az Antiquitates megjelenéséről lásd Sánta Sára, Az elsö magyar városmonográfia kiadása Schönvisner István és Szily János levelezésének tükrében = Magyar Könyvszemle, 2(2019), 202-218.

6 1791. december 21. Szombathelyi Egyházmegyei Levéltár (továbbiakban: SZEL), VasvárSzombathelyi Székeskáptalan Magánlevéltára (továbbiakban VSzSzK), Deposita, Adománylevelek 11 . 
könyvtár kezdeti beszerzéseit Budán intézte. Hozzáértő szakemberért pedig értelemszerüen a Királyi Tudományegyetemhez, azon belül is az Egyetemi Könyvtárhoz fordult, ahol valószínủleg Schönvisnert ajánlották neki, aki abban az időben a könyvtár másodőri pozícióját töltötte be.

Az Egyetemi Könyvtár öreként Schönvisner István feladatai közé tartozott az abolíciós könyveknek, vagyis a II. József által feloszlatott szerzetesrendek bibliotékáinak a leltározása és szétosztása is. ${ }^{7}$ A szerzetesrendek feloszlatása 1773ban, a jezsuita rend magyarországi megszüntetésével vette kezdetét, csúcspontja pedig II. József 1782-ben megszületett rendelete volt a kontemplatív rendek (pálosok, ciszterciek stb.) abolíciójáról: ${ }^{8}$ elsőként tehát a jezsuita rendházak könyvtárai kerültek az Egyetemi Könyvtárba, ahol listát kellett készíteni a beérkezett kötetekről, majd dönteni a további sorsukról.

Az egyik fő problémát az jelentette, hogy nem volt átgondolt szabályozás a szállítás és a feldolgozás menetére, így az a kezdetektől fogva hatalmas feladatokat rótt a könyvtár kisszámú és rendkívül alulfizetett munkatársaira - ahogy azt Schönvisner István egyik levelében mentegetőzve írja is Szily püspöknek. ${ }^{9}$ Az 1781-re elkészült Index Generalis alapján ${ }^{10}$ a legújabb számítások szerint csak a jezsuita rendházak esetében mintegy 75 ezer feldolgozandó kötetről beszélhetünk, ehhez csatlakozott 1782-től az újabb abolíciós könyvanyag. Arról nincsenek pontos adatok, hogy a kolostorok mekkora állománnyal rendelkeztek. Nem maradt fent ugyanis az összes katalógus, a 140 feloszlatott rendházból mindössze 97-től rendelkezünk eredeti katalógussal, ${ }^{11}$ így pontosan nem lehet megmondani, hogy ezekből hány kötet került az Egyetemi Könyvtárba. A becslések alapján a könyvtár mindössze négy (!) munkatársának a jezsuita, és a későbbi kolostori abolíció során mintegy negyedmillió kötetet kellett átnézni. Ezeket 1782 után már nem szállították Pestre, a könyvtárosok helyben, a kolostorokban nézték át és választották ki azokat, amelyeket aztán az Egyetemi Könyvtár gyüjteményébe olvasztottak. Így a számítások szerint körülbelül 50 ezer kötet kerülhetett Pestre, amelynek mintegy felét aukciókon értékesítették, a könyvtár magának 7-8 ezer példányt tartott meg, a többi oktatási intézményekhez került. ${ }^{12}$

7 Tóth András, Az Egyetemi Könyvtár története a szerzetesrendek feloszlatása korában (17731790) = Az Egyetemi Könyvtár Évkönyvei, 3(1966), 101-146, és BRUCKNER János, A jozefinista kultúrpolitika és az Egyetemi Könyvtár 1780-1784 = Magyar Könyvszemle, 72(1956), 112-138.

${ }^{8}$ A témáról lásd bővebben: Velladics Márta, Szerzetesrendi abolició Magyarországon $(1782-1790)=$ Levéltári Közlemények, 71(2000), 33-52.

9 [...] praeterea occupationes cum aliae, tum circa Bibliothecam Universitatis hoc anno solito plures, et molestiores, quos causant libri abolitorum monasteriorum et seminariorum [...] SZEK Szily II. 6. Schönvisner, 4. Schönvisner István levele. Buda, 1787. május 17.

${ }^{10}$ Kézirata az Egyetemi Könyvtárban található: EK Mss. J 94. és Tóтн 1966, i. m. 132.

11 Velladics 2000, i. m. 46.

12 Velladics 2000, i. m. 47-48. 
Az Egyetemi Könyvtárban keletkezett duplumok eladásával tehát igen nagy mennyiségü régi könyv került a piacra, amelyek nagymértékben fellendítették a hazai bibliofíliát. ${ }^{13}$ Ezt bizonyítja többek között a szombathelyi püspöki könyvtár kialakulása is, amely nagy részben ezeken az aukciókon értékesített könyvekből épült fel.

\section{Szily János és könyvtára}

A szombathelyi szeminárium épülete már 1780-ra elkészült, így minden lehetőség adott volt, hogy a könyvek beszerzése után a könyvtár is megnyílhasson. A püspök ezen szándéka azonban még évekig nem valósulhatott meg. II. József 1783-ban rendeletet hozott az állami szemináriumok felállításáról: eszerint a vidéki papneveldék megszüntek, azok helyét az általános szemináriumok (seminarium generale) vették át Pozsonyban és Pesten. ${ }^{14}$ Szily többször is felszólalt a császár politikája ellen, II. József ezért ki is utasította Bécsből a püspököt, és arra kötelezte, hogy a Helytartótanács elött adjon számot ellenzéki magatartásáról. ${ }^{15}$ Emellett a föpap annak a véleményének is hangot adott, hogy állítsák vissza a papnevelés régi rendszerét, ám erre már csak II. József halála után került sor. A püspök azonban eme küzdelmes évek során sem tétlenkedett könyvtárának felállítása ügyében.

Szily és Schönvisner levelezése ma a Szombathelyi Egyházmegyei Könyvtár kézirattárában található. ${ }^{16} \mathrm{Az}$ iratcsomóban a Schönvisner által küldött eredeti levelek és Szily fogalmazványai találhatók. Sajnos nem maradt fent az összes levélváltásuk, de a levelek alapján így is képet kaphatunk arról, hogy hogyan is zajlott a püspöki könyvtár megalapozása. A könyvek beszerzésénél ironikus módon igen nagy segítséget jelentett, hogy a feloszlatott szerzetesrendek könyvei, vagy legalábbis azok egy része az Egyetemi Könyvtárba került, így arra Schönvisnernek is volt rálátása. Amint már említettem, az Egyetemi Könyvtárba érkező hatalmas mennyiségü abolíciós könyvanyag mintegy felét - például a duplumokat - árveréseken értékesítették. ${ }^{17}$ Schönvisner az árverési katalógusok tételeit elküldte a püspöknek, amikor azok között felbukkant egy-egy olyan mü, amely a könyvtárából még hiányzott. ${ }^{18}$

13 A 18. század bibliofíliájáról lásd még MoNOK István, A hagyományos világ átváltozásai, Budapest-Eger, Kossuth Kiadó-Eszterházy Károly Egyetem, 2018 (Kulturális Örökség), 179-198.

14 KosÁry Domokos, Müvelödés a XVIII. századi Magyarországon, Bp., Akadémiai, 1983, 379.

15 GÉFIn Gyula, A szombathelyi egyházmegye története I. Szombathely, Martineum Könyvnyomda Részvénytársaság, 1929, 54-56.

16 SZEK Szily II., a városmonográfiával kapcsolatos levelezés, jelzet nélkül, valamint a már említett, a könyvtár alapításával kapcsolatos levelek: SZEK Szily III.

17 Az aukcióra került könyvek hatalmas mennyiségét jelzi, hogy még az 1830-as években is az abolíciós köteteket árverezték. VELLADICs 2000, i. m. 47.

18 Meg kell jegyeznünk, hogy a püspöki könyvtár kialakulásában természetesen nem játszott kizárólagos szerepet Schönvisner István. Szombathelyen ugyanis - ahogy azt már Sill Aba Ferenc is megállapította - már a 16. században is volt egy főpapi magánkönyvtár, valamint talán a Vasvár- 
Szily János teljes könyvtárát átnézve átfogó képet kaphatnánk arról, hogy az 1791-ben megnyitott gyüjjteménybe mely feloszlatott szerzetesrendi könyvtárak anyagából kerültek példányok. Ezt a jövőben tervezem is feldolgozni, jelen tanulmányban azonban egyelőre arra teszek kísérletet, hogy azokat a köteteket azonosítsam, illetve azoknak vizsgáljam a provenienciáját, amelyeket biztosan aukción vásároltak - tehát ismerjük a püspök és Schönvisner levelezéséből. A levelek mellett a könyvtár első fennmaradt katalógusát is felhasználtam. ${ }^{19}$

Biztosak lehetünk benne, hogy a könyvtár alapításakor, 1791-ben volt már egy katalógus, hiszen azt az alapítóvelében is említik, ${ }^{20}$ ám ez napjainkig nem került elő. Igy egyelőre csak az első fennmaradt kéziratos katalógust forgathatjuk, amely a Catalogus Librorum Cathedralis Ecclesiae Sabariensis címet viseli, és valamikor az 1800-as évek elején keletkezett (a legkésőbbi kiadás, amely szerepel benne, 1803-as). Nyolc szakra bontva listázza a püspöki könyvtárban található mintegy ezer kötetet, azonban biztos, hogy nem tartalmazza az összes, ekkor már meglévő példányt. Egyfelől ez a szám igen csekély, másfelől vannak olyan nyomtatványok, amelyek ekkor már biztosan a könyvtárban voltak, a katalógus ismeretlen szerzője mégsem tüntette fel azokat. ${ }^{21}$

A már említett nyolc szak a következő: 1) Scripturistae et Concionatores bibliamagyarázók és hitszónokok (165 mü), 2) Libri SS. Canones Pertractantes - kánonjogi könyvek (164 mü), 3) Sancti Patres - egyházatyák (49 mü), 4) Libri Theologici Dogmatici et Morales - teológiai, dogmatikai és erkölcsfilozófiai könyvek (95 mü), 5) Scriptores Ecclesiasticae Historiae - egyháztörténet-írók (100 mü), 6) Historici Profani - világi történetírók (164 mü), 7) Philosophici et Auctores Classici - antik filozófusok és auktorok (233 mü), 8) Libri Haeresiarchum - vezetó eretnek írók müvei (29 mü). A szakokon belül minden bizonnyal helyrajzi rend szerint találjuk az egyes müveket, szám szerint összesen 999 címet. A mü szerzőjén és címén kívül feltüntették a megjelenés helyét és idejét, valamint a formátumot és az adott cím alatti kötetek számát.

A könyvtár első fennmaradt katalógusa alapján tehát láthatjuk, hogy - hasonlóan a kor főpapi könyvtáraihoz - Szily János könyvei is általában hittudományi témájúak. Megtaláljuk közöttük a korai egyházatyák összes müveinek számos kiadását, Szentírás-magyarázatokat, valamint egyháztörténeti műveket is. Szily ezek mellett ugyanakkor különböző lexikonokat, szótárakat (például egy tizenegy nyelvü Calepinus-szótárat), valamint klasszikus auktorok kiadásait is megvásárolta könyvtára számára. Érdekes azonban, hogy a püspök

\footnotetext{
Szombathelyi Székeskáptalan is rendelkezett könyvtárral, amelyekből szintén kerülhettek kötetek az 1791-ben megnyílt püspöki könyvtárba. SiLl 1993, i. m. 97.

19 SZEK, jelzete: Ös XXIX. alsó polc.

${ }^{20}[\ldots]$ totam Bibliothecam nostram juxta Catalogum Librorum a Nobis confectum et subscriptum [...] SZEL, VSzSzK, Deposita, Adománylevelek 11.

${ }^{21}$ PATAKi 1977, i. m. 441.
} 
könyvtárának mintegy ötödét érdeklődésének megfelelően ${ }^{22}$ antikvariánus és történelmi témájú (Historici profani) mủvek tették ki, amelyekből összesen 164 darabot találhatunk a katalógusban. Ha összehasonlítjuk ezt a kor más nagy főpapi könyvtáraival, azt láthatjuk, hogy a szombathelyi püspöki könyvtárban a magyar és egyetemes történelemmel kapcsolatos munkák jóval nagyobb arányban találhatók meg.

Összehasonlításképpen érdemes megnézni például Patachich Ádám nagyváradi püspök, későbbi kalocsai érsek magánkönyvtárát (Bibliotheca Patachiana) ${ }^{23}$ Igaz ugyan, hogy a történeti müvek Patachich könyvtárában is nagy számban képviseltetik magukat - hiszen ő szintén arra törekedett, hogy a teológia mellett a világi tudományok újabb eredményei is megjelenhessenek gyüjteményében -, mégis, az 1760-es évekből fennmaradt tárgyi katalógus szerint a katalogizált 713 müből mindössze 83 volt ilyen témájú, vagyis arányaiban jóval kevesebb, mint Szily könyvtárában. Patachich a kor szellemének megfelelö enciklopédikus magánkönyvtárát - amelyet Mariosa Jakab könyvtáros segítségével épített fel - kalocsai érsekké kinevezése után 1782-ben egyesítette kalocsai káptalan könyvtárával. Emellett ő is széleskörü beszerzéseket folytatott. Ennek eredményeképpen gyüjteménye 1783-ban már több mint 16 ezer kötetet számlált, amely megelőzte még az Egyetemi Könyvtár akkori kötetszámát is. Érdemes továbbá megemlíteni, hogy egy 1783-ban készült kimutatás szerint az ország egyetlen állami, oktatási célokat szolgáló gyüjteményében, az Egyetemi Könyvtárban a történelmi témájú müvek aránya szintén mindössze $10 \%$ volt. ${ }^{24}$

Tény, hogy Szily minden bizonnyal könyvtára felépítésében is lépést akart tartani a 18. századi tudományossággal, hiszen a forráskutatással, adatgyüjtéssel és azok tudományos feldolgozásával ekkor született meg a mai értelemben vett történelemtudomány. ${ }^{25}$ Ám a könyvtárban található történeti müvek nagy számát akár az is indokolhatja, hogy az 1780-as években és az 1790-es évek elején Schönvisner István gondoskodott a kötetek beszerzéséről. A tudós ex-jezsuita ugyanis amellett, hogy az Egyetemi Könyvtár munkatársa volt, a Pesti Egyetemen az érem- és régiségtan professzoraként is müködött, valamint - ahogy már említettem - Szily püspök kérésére megírta Savaria-Szombathely történetét az ókortól egészen 1791-ig. Schönvisner ezért nem csak könyvtárosi - tehát valódi bibliofil - szemmel válogat-

${ }^{22}$ Amint már említettem, Szily ókor iránti érdeklődését minden bizonnyal a Rómában töltött tanulóévei alapozták meg.

${ }^{23}$ Boros István, A kalocsai Föszékesegyházi Könyvtár, Bp., Balassi, 1994, 26-34; Fischerné Grócz Zita, Patachich Ádám könyvtára = Patachich Ádám érsek emléke, szerk. Lakatos Adél, Kalocsa, Kalocsai Főegyházmegyei Levéltár, 2005 (A Kalocsai Főegyházmegyei Gyüjtemények kiadványai, 4), 71-74.

24 То́тн 1966, i. m. 122.

${ }^{25}$ A témáról lásd még: TóTH Gergely, A magyar történetírás kritikája és megújitásának programja az 1740-es évekböl. Bél Mátyás és a Scriptores rerum Hungaricarum = Történelmi Szemle, 55(2013), 4, 593-617; Soós István, Felzárkózás vagy lemaradás? Történetírás a 18. századi Magyarországon = Clio Inter Arma. Tanulmányok a 16-18. századi magyarországi történetírásról, szerk. Tóth Gergely, Bp., MTA BTK TTI, 2014 (Magyar történelmi emlékek, Értekezések), 227-253. 
ta a könyvtárba kerülő köteteket a püspök számára, hanem történészi szakértelemmel és alapos tárgyismerettel is. Jelen tanulmány keretei nem teszik lehetővé, hogy az összes történelmi témájú múvet bemutassam, azonban úgy gondolom, hogy érdemes ezek közül néhányat kiemelni és ismertetni. ${ }^{26}$

\section{A könyvtár történelmi témájú müvei}

A katalógus szerzője a Historici profani szak alatt összesen 164 címet listáz. Az ide sorolt címek között megtalálhatók külföldi szerzők munkái is - ezek a müvek főként valamely történelmi segédtudomány témaköréből kerülnek ki -, azonban nagy részük hazai szerző magyar történelemmel kapcsolatos műve. Elsőként nézzük a humanista történetírókat. Szily gyüjteményének része volt például Bonfini Rerum Hungaricarum decadesének Bél Károly András-féle, 1771-es kiadása (33., mai jelzete: S2r 580), és Caspar Ursinus Velius (1493-1539) költő és történetíró müve, a De bello Pannonico libri decem (49., mai jelzete: b/II 613) is. Velius a magyar koronáért I. Ferdinánd és Szapolyai János között folyó harc krónikáját írta meg befejezetlen müvében, amelyet 1762-ben jelentetett meg Bécsben Kollár Ádám Ferenc. Ki kell emelnünk Istvánffy Miklós (1538-1615) Historiájának 1724-es kölni kiadását is (34.; mai jelzete: Gb2r 313), valamint Révay Péter (1568-1522), a tudós evangélikus koronaőr De Monarchia et Sacra Corona Regni Hungariae címü, 1659-ben Frankfurtban megjelent munkáját (45., mai jelzet: Gb2r 297), amely biztosan Schönvisner jóvoltából került a püspök gyüjteményébe. ${ }^{27}$

Amint már említettem, Szily a könyvtárának felépítésében is lépést tartott korának tudományosságával: a gyüjteményében nagy számban fellelhetők például azoknak a jezsuita szerzőknek a müvei, akiket a hazai történettudomány 18. századi megteremtőinek tartunk. ${ }^{28}$ Közülük például kiemelhetjük Pray Györgyöt (1723-1801), akinek több munkája is megtalálható a katalógusban. Az Annales veteres Hunnorum, Avarum et Hungarorumban (17., mai jelzete: S2r 577) a jezsuita historikus évkönyves formában mutatta be a magyar őstörténetet, olyan magas szintü tudományos megközelítéssel, hogy a munka megjelenése után felmentették papi és tanári szolgálatai alól, hogy minden idejét ku-

\footnotetext{
${ }^{26}$ Mivel - ahogy említettem - a könyvtár első fennmaradt katalógusa a 19. század elején készült, ezért ebben a válogatásban csak azokat a mủveket ismertetem, amelyek már biztosan a könyvtár gyüjteményébe tartoztak az alapításkor is, tehát szerepel bennünk az 1791-es bejegyzés. Az adott múvek címe után zárójelben feltüntetem a kéziratos katalógusbeli sorszámukat is, valamint mai jelzetüket is a Szombathelyi Egyházmegyei Könyvtár katalógusában.

27 SZEK Szily II. 6. Schönvisner, 34. Schönvisner István levele. Buda, 1789. június 5.

${ }^{28}$ Szabados György, Jezsuita , sikertörténet” (1644-1811) = Clio Inter Arma. Tanulmányok a 16-18. századi magyarországi történetírásról, szerk. Tóth Gergely, Bp., MTA BTK TTI, 2014 (Magyar történelmi emlékek, Értekezések), 203-226.
} 
tatásainak szentelhesse. ${ }^{29}$ A tudós történetíró a könyvtárban található müvei közül megemlíthetjük még a Magyar Királyság történetét feldolgozó munkáját, az Annales Regum Hungariaet (18., mai jelzete: S2r 576), amelyben 997-töl 1564-ig tekintette át hazánk történelmét, szintén évkönyves formában. A jezsuita történetíró nemzedék legnagyobb alakjának, Katona Istvánnak szintén több művét megtaláljuk a katalógusban. Így például a Historia critica regum Hungariae... címü, negyvenkét kötetes munkájából Szily könyvtárában az 1790-ig megjelent kötetek lelhetők fel (62.; mai jelzete: y/a/III-IV 8534. és 64.; mai jelzete: : y/a/IV 8536).

A jezsuita történetírók mellett meg kell említenünk a 18. század egyéb nagy formátumú tudósait is. Elsőként Bél Mátyást (1684-1749), a történelem- és földrajztudós polihisztort, akinek több müve is Szily könyvtárának része volt: így például 1723-as Nürnbergben megjelent Prodromusa (35., mai jelzete: S2r 513), valamint az 1735 és 1746 között részenként megjelent, történelmi forrásokat közlö Adparatus ad historiam Hungariae... (41., mai jelzete: S2r 521) címü munkája. A katalógusban megtaláljuk a Bél Mátyás előszavával, Johann Georg Schwandtner által 1746-48-ban kiadott Scriptores Rerum Hungaricarumot is (32., mai jelzete: S2r 579), amely elsőként tartalmazta a magyar történelem legfontosabb elbeszélő forrásait, köztük Anonymus krónikáját. ${ }^{30}$

Amint említettem, nem csak magyar, hanem külföldi szerzőket is találunk a katalógus történeti műveket felsoroló szakjában, azonban ezen müvek nagy része valamely történelmi segédtudomány témájában íródott. Mivel a 18. század eme tudományágak kialakulásáról és fejlődéséről is nevezetes, nem meglepő, hogy Szily igyekezett beszerezni könyvtára számára az ilyen tematikájú múveket is. A gyüjtemény része volt például Jean Mabillon (1632-1707) alapvető munkája, a De re diplomatica (9., mai jelzete: Ga2r 322), amely múvével a francia tudós megteremtette az oklevéltan alapjait.

Amelyek pedig leginkább Szily püspök érdeklődésére tartottak számot: régiségtani múvek is nagy számban találhatók a katalógusban. A könyvtár történeti munkáinak listáját a katalógus szerzője mindjárt két antikvariánus ,,alapmüvel" kezdi: Johann Georg Graevius Thesaurus antiquitatum Romanarum címü munkájának tizenkét kötete (2., mai jelzete: Ga2r 328), valamint Jacob Gronovius Thesaurus antiquitatum Graecaruma (1., mai jelzete: Ga2r 338), szintén tizenkét kötettel már az alapításkor a gyüjtemény része volt. Ezen kívül kiemelhetjük Flavius Blondus (Flavio Biondo 1392-1463) Roma triumphans címü, 1531-ben Baselben megjelent munkáját (23., mai jelzete: Gb2r 340). A humanista Blondus volt az első régiségbúvár, aki már nem csak megfigyelte és leírta Róma ókori építészeti emlékeit és a feliratokat, hanem az azokból kiaknázható információkat fel is használta a történelem rekonstruálására. A Roma triumphans című müvében Biondo elsőként mutatja be módszeres felméréssel

29 Szabados 2014, i. m. 213.

30 Тóth 2013, i. m. 
az ókori Róma vallási, közigazgatási, hadászati és egyéb intézményeit. ${ }^{31}$ A katalógusban megtaláljuk Albert-Henri de Sallengre Novus thesaurus antiquitatumának három kötetét is (3., mai jelzete: Ga2r 330), amellyel a szerző az előszóban olvasható gondolatai szerint arra törekedett, hogy Graevius és Gronovius munkáit új ismeretekkel kiegészítse. ${ }^{32}$

Szily feliratgyüjteményből is többet beszerzett könyvtára számára: így például Antonio Muratori Novus thesaurus veterum inscriptionum címü, 1739-ben megjelent, négykötetes munkáját (8., mai jelzete: Ga2r 321). Végezetül pedig még egy szerzőt meg kell említenünk, akinek több müvét is megtaláljuk Szily könyvtárában: Schönvisner Istvánt. A könyvtár alapításáig megjelent összes müvét fellelhetjük a katalógusban: így természetesen a Szombathely történetét feldolgozó Antiquitatum et Historiae Sabariensis... címü, 1791-ben megjelent munkáját (47., mai jelzete: XIV/d 32053), földrajzi-történeti múvét, az In Romanorum iter per Pannoniae ripamot (88., mai jelzete: XX/e 23932), valamint az első aquincumi régészeti ásatást és annak eredményeit bemutató, De ruderibus laconici caldariique Romanit (95., mai jelzete: Gb2r 352.) is.

Schönvisner tehát a könyvtárba beérkezett abolíciós könyvek közül válogatott a püspöknek, és küldte el az árverésekre kerülő példányok közül azokat, melyek Szily érdeklődésére tarthattak számot. Részletes árverési tételekkel összesen hat levél található ma Szily János iratai között, ${ }^{33}$ de a levelezésük során Schönvisner számtalan esetben felhívja a püspök figyelmét megvásárolandó könyvekre akkor is, amikor éppen nem a könyvtárral kapcsolatos problémákat tárgyalják. A püspök és Schönvisner levelezéséből cím szerint összesen harminc, Pesten megvásárolt müröl tudunk. ${ }^{34}$ Annak ellenére, hogy sajnos kevés ilyen témájú levelük maradt fent, ezeknek a levélváltásoknak köszönhetően is láthatjuk, hogy Szily milyen bibliofil gondossággal építette fel könyvtárát.

A levelezésből további érdekes adatok is kiderülnek: például a megvásárolt könyvek áráról is tudomást szerezhetünk. A legdrágább beszerzés ennek alapján a nevezetes bollandista kiadványsorozat, az Acta Sanctorum volt, az ötvenkét kötet összesen 320 forintba került (összehasonlításképpen: Schönvisner éves fi-

31 Burke, Peter, The Renaissance Sense of the Past, London, Edward Arnold, 1969, 25.

32 De Sallengre, Albert-Henri, Novus Thesaurus Antiquitatum Romanarum, Venetiis, Typis Jo. Baptistae Pasquali, 1735, [1].

33 SZEK Szily II. 6. Schönvisner, 12. Schönvisner István levele. Buda, 1787. november 7., SZEK Szily II. 6. Schönvisner, 15. Schönvisner István levele. Buda, 1787. december 1., SZEK Szily II. 6. Schönvisner, 24. Schönvisner István levele. Buda, 1788. május 28., SZEK Szily II. 6. Schönvisner, 27. Schönvisner István levele. Buda, 1788. július 21., SZEK Szily II. 6. Schönvisner, 34. Schönvisner István levele. Buda, 1789. június 5., SZEK Szily II. 6. Schönvisner, 36. Schönvisner István levele. Buda, 1789. június 19.

${ }^{34}$ Ez a szám tehát a biztosan azonosítható könyvekre vonatkozik. Mivel - amint már említettem - a püspök levelezésében nem találunk adatot arra, hogy a könyvtár megnyitását megelőző időkben mással is tárgyalt volna könyvbeszerzéssel kapcsolatban, szinte biztosra mondhatjuk, hogy az 1791-ig beszerzett kötetek nagy részét Schönvisner vásárolta számára. A tudós és a püspök több mint öt éven át tartó levelezése (amelynek csak a töredéke maradt fent) bizonyítja tartós együttmüködésüket. 
zetése könyvtárosként ekkor - 1787-ben - 500 forint volt). ${ }^{35} \mathrm{~A}$ Schönvisner által beszerzett könyvek ma is az Egyházmegyei Könyvtár gyüjteményét gazdagítják, bennük pedig - általában a címlapon - Szily saját kezü bejegyzését olvashatjuk: Cath. Eccl. Sabar. Anno 1791.

Szily a bibliotékáját kezdettől fogva a köz használatára szánta. ${ }^{36}$ Hazánkban így ő volt a harmadik föpap - Klimo György pécsi püspök ${ }^{37}$ és a már említett Patachich Ádám kalocsai érsek után -, aki megnyitotta könyvtárát a müvelt nagyközönség számára is. Szily könyvtárát az alapítólevelében kifejtett szándéka szerint az épülő székesegyháznak adományozta (Cathedrali Ecclesiae nostrae Sabariensi donaverimus), és az éppen megnyílt szemináriumban helyezte el azzal a kikötéssel, hogy az mindig ott maradjon. Ebben a gesztusban - ti., hogy a székesegyháznak ajánlja gyüjteményét - Szily múlt iránti tiszteletét figyelhetjük meg: évszázadokon át a székesegyházakban őrizték ugyanis például az összegyüjtött liturgikus könyveket, de a káptalanok levéltárát is. ${ }^{38}$ Mindez nyilvánvalóan nem volt lehetséges egy ekkora gyüjtemény esetében, így Szily gondoskodott arról, hogy a szemináriumban megfelelően el lehessen helyezni a könyvtárat.

A szeminárium épületének két termét, ahol a könyvtár helyet kapott, a püspöki palotához hasonlóan Stephan Dorffmaister színpompás freskói díszítik, a bútorzatot és a könyvszekrényeket Melchior Hefele, a Szombathelyi székesegyház tiroli származású építőmestere készítette. Szily könyvtára 1791-ben nyílt meg: a püspök december 21 -én kelt alapítólevelében a gondosan válogatott gyüjteményt (többek között 15 kódexszel és 96 ősnyomtatvánnyal) a szeminaristák és tanáraik, valamint bizonyos napokon az érdeklődő nagyközönség számára is elérhetővé tette. ${ }^{39}$

35 То́тн 1966, i. m. 125.

36 [...] Cathedrali Ecclesiae nostrae Sabariensi donaverimus, et in eandem transtulerimus [...] quatenus illam tum Professores Clericorum, tum ipsi Alumni opportune adire queant [...] SZEL, VSzSzK, Deposita, Adománylevelek 11.

37 Klimo püspök nyilvános gyűjteménye a legújabb számítások szerint körülbelül 8 ezer kötetet tartalmazott; a föpap célul tűzte ki az összes tudományág alapvető köteteinek gyüjtését. Könyvtárát 1774-ben nyitotta meg a köz számára. РонÁNKA Éva, A nyilvános pécsi püspöki könyvtár berendezésének és állományának „rekonstrukciója” = Klimo György püspök és kora. Egyház, müvelödés és kultúra a 18. században, szerk. Pohánka Éva, Szilágyi Mariann, Pécs, Pécsi Tudományegyetem Egyetemi Könyvtára, 2011, 17-27.

38 SiLl 1993, i. m. 99.

39 Imo, ut tanto major ex hac Bibliotheca in publicum utilitatis dimanet, volumus ac ordinamus, ut non solum Ecclesiasticis ac Religiosis, verum etiam secularibus personis ad eam accessus suis temporibus pateat. [...] SZEL, VSzSzK, Deposita, Adománylevelek 11. 


\section{A Schönvisner által vásárolt kötetek provenienciája ${ }^{40}$}

Érdemes még megvizsgálni a püspöki könytárba került kötetek provenienciáját is. Ezek elemzése több szempontól is haszonnal járhat. Leginkább ahhoz járul hozzá, hogy adalékokat szolgáltasson a feloszlatott szerzetesrendi könyvtárak rekonstruálásához, hiszen azok közül soknak nem maradt fent katalógusa az abolíció korából, így tehát csak feltételezésekkel élhetünk arra nézve, hogy milyen állománnyal rendelkeztek. Amint már említettem, a levelezésből összesen harminc olyan müröl tudunk, amelyet a föpap biztosan Schönvisneren keresztül vásárolt a pesti könyvaukciókon. Ezeket azonosítva azt látjuk, hogy összesen tíz kolostor könyvtárából kerültek Szombathelyre, amelyek a következők:

\begin{tabular}{|c|l|l|}
\hline 1 & $\begin{array}{l}\text { Bibliothecae Pestiens. Ord. S. Pauli P. } \\
\text { E. Inscriptus An. 1767. }\end{array}$ & $\begin{array}{l}\text { A pálos rend pesti könyvtárának } \\
\text { ragasztott, metszetes ex librise. }\end{array}$ \\
\hline 2 & $\begin{array}{l}\text { Inscriptus Bibliothecae Conventus (S. } \\
\text { P. Or. S.) Sancti pr. Eremit. 1767. }\end{array}$ & $\begin{array}{l}\text { Egy pálos kolostor }{ }^{41} \text { könyvtárából, } \\
\text { kézírással. }\end{array}$ \\
\hline 3 & $\begin{array}{l}\text { Bibliothecae Conv. Ma[ria]e Thall. Sub } \\
\text { Prioratu R. P. Bartholomei Orlay 1767. }\end{array}$ & $\begin{array}{l}\text { A máriavölgyi pálos kolostor könyvtá- } \\
\text { rából, kézíssal. }\end{array}$ \\
\hline 4 & $\begin{array}{l}\text { Inscriptus Catalogo Residentiae Soc. } \\
\text { Jesu. Comaromiensis 1749. }\end{array}$ & $\begin{array}{l}\text { A komáromi jezsuita kollégium } \\
\text { könyvtárából, kézírással. }\end{array}$ \\
\hline 5 & Conv. Lucensis & $\begin{array}{l}\text { A loukai (Klosterbruck) premontrei } \\
\text { apátság könyvtárából, kézírással. }\end{array}$ \\
\hline 6 & Collegii Agriensis SJ. 1751. & $\begin{array}{l}\text { Az egri jezsuita kollégium könyvtárá- } \\
\text { ból, kézírással. }\end{array}$ \\
\hline 7 & $\begin{array}{l}\text { Monasterii Ujhelyiensis Ordinis S. } \\
\text { Pauli Eremit. }\end{array}$ & $\begin{array}{l}\text { A sátoraljaújhelyi pálosok kolostorának } \\
\text { könyvtárából, kézírással }\end{array}$ \\
\hline 8 & $\begin{array}{l}\text { Ordinis S. Pauli Primi Erem. Monast. } \\
\text { Catalogo Inscript. }\end{array}$ & $\begin{array}{l}\text { Egyª́ pálos kolostor könyvtárából, } \\
\text { kézíssal. }\end{array}$ \\
\hline 9 & $\begin{array}{l}\text { Conventus Posoniensis Ordinis S(anc) } \\
\text { t(issi)mae Trinitatis et Redemp. Captl. }\end{array}$ & $\begin{array}{l}\text { A pozsonyi trinitárius rend könyvtárá- } \\
\text { ból, kézírással. }\end{array}$ \\
\hline 10 & $\begin{array}{l}\text { Conventus Posoniensis P.P. Trinitario- } \\
\text { rum }\end{array}$ & $\begin{array}{l}\text { A pozsonyi trinitárius rend könyvtárá- } \\
\text { ból, kézírással. }\end{array}$ \\
\hline 11 & $\begin{array}{l}\text { Conventus Wondorffensis ord. S. Pauli } \\
\text { Primi Eremitae }\end{array}$ & $\begin{array}{l}\text { A sopronbánfalvai pálos kolostor } \\
\text { könyvtárából, kézírással. }\end{array}$ \\
\hline 12 & Monast. Tihany. O. S. Bened. & $\begin{array}{l}\text { A tihanyi bencés kolostor könyvtárából, } \\
\text { kézísással. }\end{array}$ \\
\hline
\end{tabular}

40 A könyvtár 1791-es állományának azonosítása további kutatást igényel: ezen kötetek provenienciájának vizsgálatából megállapítható lesz, hogy Schönvisner mekkora szerepet játszott a könyvtár 1791 előtti beszerzéseiben.

${ }^{41}$ A bejegyzés ugyanabban a müben található, amelyben pesti pálos könyvtár ragasztott, metszetes ex librise, ezért feltételezhetjük, hogy szintén a pesti rendház tulajdona volt.

42 A bejegyzés ugyanabban a müben található, amelyben a sátoraljaújhelyi kolostor bejegyzése, ezért itt szintén feltételezhetjük a sátoraljaújhelyi provenienciát. 
Láthatjuk tehát, hogy a pesti, a máriavölgyi, a sátoraljaújhelyi és sopronbánfalvai pálosok, a komáromi és egri jezsuiták, a pozsonyi trinitáriusok, és a loukai premontreiek könyvtáraiból kerültek kötetek a szombathelyi könyvtárba Schönvisner közbenjárásával. Ez a néhány adat is jól mutatja, hogy milyen utat jártak be a megszüntetett szerzetesrendi könyvtárak kötetei: azok részben a már meglévő, részben az újonnan létrejövő föpapi bibliotékákba vándoroltak át, így azok állományát ebből a szempontból is érdekes lehet vizsgálni.

\title{
Összegzés
}

Szily Jánosnak, Szombathely első püspökének a könytáralapítása nem volt zökkenőmentes. Az intézmény megnyitását nagyban akadályozták II. József rendeletei, hiszen a 18. század végén az abszolutista Habsburg kormányzat drasztikusan beleszólt az egyházak életébe, s ehhez a föpapoknak is alkalmazkodniuk kellett. Szily - ahogy fentebb utaltunk rá - erősen ellenállt az uralkodói intézkedéseknek, és ebben a nehéz időszakban sem tétlenkedett könyvtárának létrehozása terén. Segítője ekkor Schönvisner István volt, aki jezsuita lévén szintén megszenvedte az abolíciós intézkedéseket. Rendjének felszámolása után sok más szerzeteshez hasonlóan világi papként az oktatásban helyezkedett el és a tanítás mellett elöször az Egyetemi Könyvtárban, majd az egyetem érem- és régiségtárában kezdett dolgozni.

Paradox módon éppen a drasztikus abolíciós intézkedések vezettek ahhoz, hogy a püspök igazi bibliofil könyvtárat tudott létrehozni, hiszen egyfelöl a feloszlatott szerzetesrendek könyvállományának értékesítése fellendítette a régi könyvek piacát, másfelöl Schönvisner István az Egyetemi Könyvtár őreként hatékonyan tudott segíteni Szilynek a könyvek beszerzésében. Habár e könyvek számos régi bibliotéka megszüntetése nyomán kerültek a könyvpiacra, viszont megjelenésükkel elősegítették napjainkig is meglévő értékes müemlékkönyvtárak létrejöttét, azok tulajdonosai pedig vásárlásaikkal megmentették e könyveket attól, hogy külföldre kerüljenek, vagy legrosszabb esetben elkallódjanak és megsemmisüljenek.

\author{
Sánta, Sára
}

\section{István Schönvisner and the foundation of the Episcopal Library of Szombathely}

One of the first measures of János Szily (1735-1799), the first bishop of the Diocese of Szombathely, was to open a library. Initially, István Schönvisner (1738-1818), the custos of the University Library of Pest assisted him to compile the library's fund. In the present paper, I would like to explain a detail from the process of the library's foundation, which is specifically related to Schönvisner. 
After describing the process of handling the banned books from the monastic orders' libraries dissolved by Emperor Joseph II, an attempt to present the thematic distribution of the works acquired by Schönvisner will be made. I aim to elaborate the copies of the section Historici Profani. Based on the examination of their provenance, identification of the dissolved monastic libraries, from which the books of the new library originated, will be offered.

Keywords: $18^{\text {th }}$ century, Monastic libraries, University Library, István Schönvisner. 